\title{
PERBAIKAN PROSES FERMENTASI BIJI KAKAO KERING DENGAN PENAMBAHAN TETES TEBU, KHAMIR, DAN BAKTERI ASAM ASETAT
}

\author{
Donny Widianto, Ajeng Dara Pramita, dan Sri Wedhastri, \\ Program Studi Bioteknologi Sekolah Pascasarjana Universitas Gadjah Mada \\ Email: donny@ugm.ac.id.
}

\begin{abstract}
Most of cocoa beans produced by smallholder farmers were non fermented which can be improved by modified fermentation processing. This study was aimed to inverstigate the influence of molasses, yeast Saccharomyces cerevisiae, and Acetobacter aceti addition on dried cocoa beans fermentation process.

Fresh cocoa beans were dried in a glasshouse and its reducing sugar was analyzed before and after drying. A small plastic bucket (20 cm diameter and $30 \mathrm{~cm}$ height) with aeration holes was used as fermentation vessel. Dried cocoa beans were soaked in distilled water for 4 hours, inoculated with yeast and acetic acid bacteria cultures, and molasses were added at two different concentration, i.e, 1 and 1.5 times of reducing sugar lost during drying. Reducing sugar, ethanol, titrated acid, population of yeast, and acetic acid bacteria were monitored during fermentation. After fermentation the beans were sun dried and its $\mathrm{pH}$ and degree of fermentation were determined to assess the bean quality.

The results showed that the addition of molasses mostly at the level of 1.5, S. cerevisiae, and A. aceti increase reducing sugar, ethanol, titrated acid, yeast and acetic acid bacteria of fermentation liquid (pulp). The highest percentage of fermented beans $(68.4 \%)$ was achieved by addition of S. cerevisiae, A. aceti, and molasses at the level 1.5. It is likely that the addition of S. cerevisiae, A. aceti, and molasses could improve fermentation processing of dried cocoa bean.
\end{abstract}

Keywords: molasses, Saccharomyces cerevisiae, Acetobacter aceti, dried cocoa beanfermentation.

\section{ABSTRAK}

Sebagian besar biji kakao yang dihasilkan petani Indonesia merupakan kakao kering non-fermentasi yang kualitasnya masih dapat ditingkatkan dengan metode fermentasi, tetapi dibutuhkan optimasi agar fermentasi dapat berjalan dengan baik.Penelitian ini dilakukan untuk mengetahui pengaruh dari pemberian tetes tebu, khamir Saccharomyces cerevisiae, dan bakteri Acetobacter aceti pada fermentasi biji kakao kering.

Biji kakao kering diperoleh dengan mengeringkan biji kakao basah (segar) di rumah kaca, dan masing ditentukan kadar gula reduksinya. Percobaan fermentasi biji kakao kering dilakukan dalam ember $(\mathrm{d}=20 \mathrm{~cm}, \mathrm{t}=30 \mathrm{~cm})$ yang diberi lubang untuk aerasi diameter $0,5 \mathrm{~cm}$ dan jarak antar-lubang $10 \mathrm{~cm}$. Biji kakao kering dibasahi kembali melalui perendaman dalam air destilat steril selama 4 jam. Penambahan biakan Saccharomyces cerevisiae dan Acetobacter aceti dilakukan pada saat perendaman. Penambahan tetes tebu dilakukan dalam duavariasi yaitu , 1 dan 1,5 kali kadar gula reduksi yang hilang 
karena pengeringan. Kakao diinkubasi selama enam hari dan dibalik setiap dua hari sekali. Setiap perlakuan diulangi tiga kali dan diamati tiap dua hari sekali. Kadar gula reduksi, kadar etanol, kadar asam tertitrasi, populasi khamir, dan bakteri asam asetat dalam pulp /cairan fermentasi diamati selama proses fermentasi. Untuk mengetahui kualitas biji kakao kering dilakukan pengukuran $\mathrm{pH}$, dan uji belah pada biji kakao kering.

Pemberian tetes tebu terutama pada dosis 1,5 dan biakan meningkatkan kadar gula reduksi dan kadar etanol, kadar asam tertitrasi, populasi khamir, dan bakteri asam asetat pada pulp/ cairan fermentasi. Penambahan biakan dan tetes tebu dengan dosis 1,5 memberikan jumlah biji terfermentasi tertinggi yaitu $68,4 \%$, sehingga dapat disimpulkan bahwa penambahan tetes tebu, khamir, dan bakteri asam asetat dapat memperbaiki proses fermentasi biji kakao kering.

Kata kunci: tetes tebu, Saccharomyces cerevisiae, Acetobacter aceti, fermentasi, bijikakao kering.

\section{PENGANTAR}

Fermentasi kakao pada dasarnya adalah proses perombakan gula dan asam sitrat dalam pulp menjadi asam-asam organik yang dilakukan oleh konsorsium mikrobia pelaku fermentasi (Lopez dan Dimick, 1996; Ardhana dan Fleet, 2003). Asam-asam organik tersebut akan menginduksi reaksi enzimatik yang ada di dalam biji sehingga terjadi perubahan biokimia yang akan membentuk senyawa yang memberi aroma, rasa, dan warna pada kakao (Wood dan Lass, 2001; Biehl, 1986). Proses ini dilakukan dengan cara memeram biji kakao pada wadah tertutup selama 5-7 hari dengan disertai pembalikan setiap 2 hari sekali. Tanpa melalui proses fermentasi biji kakao akan terasa pahit, sepat, dan tidak akan menghasilkan aroma khas cokelat ketika diolah (Thompson dkk., 2001).

Sebagian besar biji kakao yang dihasilkan Indonesia merupakan kakao non-fermentasi, dari 780.000 ton hasil kakao Indonesia pada tahun 2008 hanya 5\% nya saja yang terfermentasi. Sebanyak 93\% kakao Indonesia dihasilkan oleh petani yang mengolah biji kakao hanya dengan pencucian dan pengeringan dengan sinar matahari tanpa melalui proses fermentasi, sedangkan $7 \%$ sisanya dihasilkan oleh sektor perkebunan baik swasta atau nasional dengan proses fermentasi (Yasa, 2004; Biro Humas Deptan, 2009).

Biji kakao kering non-fermentasi memiliki karakteristik yang berbeda dibandingkan dengan biji kakao basah yang biasa digunakan sebagai bahan untuk fermentasi sehingga sulit untuk memfermentasi kakao tersebut menggunakan metode fermentasi biji kakao basah biasa. Biji kakao kering telah kehilangan sebagian besar kandungan air dan substrat yang merupakan syarat mutlak terjadinya fermentasi kakao. Kandungan air selama fermentasi digunakan dalam reaksi enzimatik dalam biji dan pertumbuhan mikrobia di dalam pulp (Lehrian dan Patterson, 1983). Air akan mempertemukan enzim dengan substrat yang ada di dalam biji sehingga proses hidrolisis dan oksidasi senyawa calon rasa, warna, dan aroma pada kakao dapat terjadi. Kandungan air yang dibutuhkan dalam fermentasi kakao adalah lebih dari 35\%. Substrat adalah bahan yang dirombak oleh mikrobia selama proses fermentasi. Substrat dalam fermentasi biji kakao adalah gula dan asam sitrat yang terkandung dalam pulp (Lopez dan Dimick, 1996). Selama proses fermentasi pulp akan dirombak oleh mikrobia menjadi asam-asam organik. Asam akan berdifusi masuk ke dalam biji dan menginduksi reaksi enzimatik untuk membentuk senyawa calon rasa, aroma dan warna (Wood dan Lass, 2001; Biehl, 1986). Mengacu pada hal tersebut diperlukan upaya pengembalian kandungan air dan substrat biji kakao kering ke kondisi semula sebelum fermentasi dilakukan.

Penelitian fermentasi kakao menggunakan biji kakao kering non-fermentasi telah berhasil dilakukan di laboratorium Mikrobiologi Fakultas Pertanian UGM, tetapi jumlah biji kakao terfermentasi belum sesuai Standar Nasional Indonesia 
(SNI) dan standar kakao untuk industri makanan dan minuman (Hapsari dkk., 2007). Penelitian ini ditujukan untuk memperbaiki proses fermentasi biji kakao kering dengan menambahkan S. cerevisiae, A. aceti, dan tetes tebu pada proses fermentasi.

\section{Bahan dan Metode Penelitian Biji kakao kering}

Biji kakao yang digunakan diambil dari buah kakao masak, yaitu buah yangtelah berwarna kuning atau oranye dan mengeluarkan bunyi berongga ketika diketuk. Buah dicuci dengan air kemudian dibelah untuk dikeluarkan bijinya dan dikeringkan pada tampi bambu di bawah sinar matahari langsung sampai kandungan airnya tersisa 6 sampai $7 \%$.

\section{Analisis Pendahuluan}

Analisis pendahuluan dilakukan untuk mengetahui kadar air dan gula reduksi pada pulp dan biji kakao yang hilang selama proses pengeringan. Kadar air biji kakao ditentukan dengan menggunakan metode pemanasan biji kakao dalam oven dengan suhu $105^{\circ} \mathrm{C}$ selama semalam, sedangkan kadar gula reduksi pulp basah, pulp kering, dan tetes tebu diukur dengan metode Dinitro Salicylic Acid (DNS) (Miller, 1959).

\section{Perbanyakan Biakan Khamir dan Bakteri}

Penyiapan biakan Sacharomyces cerevisiae OUT7055 dilakukan dalam media Yeast Extract Pepton Dextrose broth (YEPDB), sedangkan biakan Acetobacter aceti disiapkan dalam media Yeast glucose broth for Acetobacter aceti yang masing-masing telah disterilkan pada suhu $121^{\circ} \mathrm{C}$ selama 15 menit. Satu ose kultur $S$. cerevisiae OUT7055 dan A. aceti dalam medium agar miring disuspensikan dalam 5 mililiter (ml) air distilasi steril, kemudian dipindahkan ke dalam $200 \mathrm{ml}$ medium cair, diinkubasi selama 24 jam di penggojok berkecepatan 30 putaran permenit, pada suhu kamar (Friend dan Shahani, 1981).

\section{Fermentasi Biji Kakao Kering}

Fermentasi dilakukan dengan meletakkan biji kakao kering dalam ember plastik (diameter $20 \mathrm{~cm}$, tinggi $30 \mathrm{~cm}$ ) yang dialasi daun pisang dan ditutup dengan plastik. Sebelum digunakan ember, daun pisang dan plastik dicuci sabun antiseptik, dan dibasuh alkohol kadar $94 \%$. Biji ditimbang sebanyak 4 $\mathrm{kg}$, ditambahkan larutan yang mengandung tetes tebu, biakan khamir dan bakteri asam asetat (2000 ml)secara bertahap sampai terserap semuanya oleh biji kakao. Jumlah biakan khamir dan bakteri asam asetat yang ditambahkan $\left(10^{6} \mathrm{cfu} / \mathrm{g}\right)$ berdasarkan jumlah biakan yang ditambahkan pada fermentasi kakao biasa (Palupi dkk., 2007), sedangkan jumlah tetes tebu yang ditambahkan berdasarkan selisih kadar gula reduksi pulp basah dan kering yang telah ditentukan pada analisis pendahuluan (1 dan 1,5 kali).

\section{Analisis Pemantauan Proses Fermentasi}

Kadar asam tertitrasi ditentukan dengan metode Cutaia (1980),kadar gula reduksi ditentukan dengan metode DNS (Miller, 1959), kadar ethanol ditentukan dengan Conway micro diffusion method,sedangkan perhitungan jumlah koloni khamir dan bakteri asam asetat dilakukan dengan metode plate count. Analisis statistik data yang diperoleh dilakukan dengan Duncan Multiple Range Test (DMRT).

\section{Pengeringan Biji Kakao Hasil Fermentasi}

Biji dikeringkan di bawah sinar matahari langsung. Penjemuran dilakukan selama 4-5 hari dan selama masa penjemuran biji dibalik dua kali sehari. Penjemuran diakhiri ketika kandungan air biji 7,5\% dan nampak berwarna cokelat atau cokelat merah (Haryadi dan Supriyanto, 1991).

\section{Analisis Biji Kakao Hasil Fermentasi}

Penentuan $\mathrm{pH}$ biji dengan metode Jinap dan Dimick (1990) dan warna kotiledon biji 
diamati dengan metode uji belah (Anon, 1970).Analisis statistik data yang diperoleh dilakukan dengan Duncan Multiple Range Test (DMRT).

\section{PEMBAHASAN}

\section{Perubahan Kandungan Gula Reduksi}

Gula reduksi merupakan hasil perombakan pektin, pati, dan sukrosa yang terkandung dalam pulp dan tetes tebu oleh mikrobia selama fermentasi. Pektin dengan bantuan enzim pektinase dipecah menjadi alkohol dan asam pektinat, kemudian asam pektinat dengan bantuan enzim pektinase dipecah menjadi galaktosa, arabinosa, dan asam asetat. Pati pada plasenta dirombak menjadi gula oleh khamir amilolitik. Sukrosa dari tetes tebu dipecah menjadi glukosa dan fruktosa oleh enzim invertase. Gula reduksi selain berfungsi sebagai bahan baku pembentukan etanol juga berfungsi sebagai senyawa calon rasa dalam biji kakao. Kandungan gula reduksi pada fermentasi biji kakao basah meningkat pada awal fermentasi dan menurun pada pertengahan fermentasi dan tetap stabil hingga akhir masa fermentasi (Lopez dan Dimick, 1996).

Kandungan gula reduksi pada penelitian ini (Tabel 1) diamati tiap dua hari sekali dan teramati kandungannya meningkat sampai pengamatan hari terakhir (enam hari). Hal ini mengindikasikan bahwa proses fermentasi biji kakao kering dalam penelitian ini berjalan lebih lambat,jika dibandingkan dengan proses fermentasi biji kakao basah seperti yang dilaporkan oleh Lopez dan Dimick (1996) dan proses fermentasinya dapat dikatakan belum berhenti dalam waktu enam hari.
Tabel 1. Kandungan Gula Reduksi dalam Cairan Fermentasi / Pulp (\%)

\begin{tabular}{lcll}
\hline \multirow{2}{*}{ Perlakuan } & \multicolumn{3}{c}{ Pengamatan Ke- } \\
\cline { 2 - 4 } & \multicolumn{1}{c}{1} & \multicolumn{1}{c}{3} \\
\hline MO & $2.49^{\mathrm{e}}$ & $5.41^{\text {bcde }}$ & $7.72^{\text {abc }}$ \\
MOI & $9.23^{\text {a }}$ & $3.57^{\text {edc }}$ & $5.85^{\text {abcde }}$ \\
MX & $6.85^{\text {abcd }}$ & $6.53^{\text {ab }}$ & $6.26^{\text {abcde }}$ \\
MXI & $2.84^{\text {de }}$ & $3.04^{\text {edc }}$ & $5.04^{\text {abcde }}$ \\
MY & $4.71^{\text {abcde }}$ & $4.49^{\text {abcde }}$ & $6.57^{\text {abed }}$ \\
MYI & $4.52^{\text {bcde }}$ & $6.40^{\text {abcde }}$ & $7.54^{\text {abcd }}$ \\
\hline
\end{tabular}

Keterangan: MO (tanpa tetes dan biakan), MOI (tanpa tetes, diberi biakan), MX (diberi tetes dosis 1, tanpa biakan), MXI (diberi tetes dosis 1dan biakan), MY (diberi tetes dosis 1,5, tanpa biakan), MYI (diberi tetes dosis 1,5 dan biakan). Angka-angka yang diikuti huruf yang sama pada setiap kolom tidak berbeda nyata pada taraf $5 \%$.

Dari Tabel 1, tampak bahwa penambahan tetes tebu pada dosis 1,5 dan penambahan (inokulasi) biakan meningkatkan kandungan gula reduksi walaupun secara statistik tidak signifikan karena proses perombakan masih belum maksimum. Jika dilihat pada perlakuan penambahan tetes tebu dosis 1 dan tanpa tetes tebu tampak bahwa inokulasi biakan justru menurunkan kandungan gula reduksi, hal ini diduga karena biakan tersebut mengkonsumsi gula reduksi dalam jumlah lebih banyak dibandingkan dengan yang tidak ditambah biakan. Hal ini akan berkonsekuensi meningkatkan aktivitas khamir dan dihasilkannya kandungan ethanol yang lebih banyak pada perlakuan yang ditambah biakan. 


\section{Perubahan Kandungan Ethanol}

Pemberian tetes tebu meningkatkan jumlah substrat yang dapat dirombak menjadi etanol, sedangkan inokulasi khamir meningkatkan jumlah mikrobia yang bekerja merombak gula reduksi menjadi etanol. Peningkatan proses fermentasi yang terjadi akibat inokulasi mikroorganisme banyak dilaporkan pada beberapa penelitian. Schwan (1998) pada penelitiannya melaporkan penambahan biakan Saccharomycescerevisiae dan beberapa biakan bakteri lain dapat meningkatkan kinerja fermentasi biji kakao. Pada penelitian ini (Tabel 2) tampak bahwa penambahan tetes tebu dan biakan meningkatkan aktivitas khamir dan kandungan ethanol.

Tabel 2. Kandungan Ethanol dalam Cairan Fermentasi (\%)

\begin{tabular}{llll}
\multicolumn{4}{c}{ Fermentasi (\%) } \\
\cline { 2 - 4 } Perlakuan & \multicolumn{3}{c}{ Hari Ke- } \\
\cline { 2 - 4 } & \multicolumn{1}{c}{$\mathbf{1}$} & \multicolumn{1}{c}{$\mathbf{3}$} \\
\hline MO & $0.39^{\mathrm{abc}}$ & $0.38^{\mathrm{abc}}$ & $0.25^{\mathrm{c}}$ \\
MOI & $0.78^{\mathrm{a}}$ & $0.75^{\mathrm{abc}}$ & $0.43^{\mathrm{abc}}$ \\
MX & $0.71^{\mathrm{ab}}$ & $0.75^{\mathrm{ab}}$ & $0.60^{\mathrm{abc}}$ \\
MXI & $0.79^{\mathrm{ab}}$ & $0.71^{\mathrm{a}}$ & $0.61^{\mathrm{abc}}$ \\
MY & $0.66^{\mathrm{ab}}$ & $0.54^{\mathrm{abc}}$ & $0.39^{\mathrm{bc}}$ \\
MYI & $0.68^{\mathrm{ab}}$ & $0.44^{\mathrm{abc}}$ & $0.45^{\mathrm{abc}}$ \\
\hline
\end{tabular}

Keterangan: MO (tanpa tetes dan biakan), MOI (tanpa tetes, diberi biakan), MX (diberi tetes dosis 1, tanpa biakan), MXI (diberi tetes dosis 1 dan biakan), MY (diberi tetes dosis 1,5, tanpa biakan), MYI (diberi tetes dosis 1,5 dan biakan). Angka-angka yang diikuti huruf yang sama pada setiap kolom tidak berbeda nyata pada taraf $5 \%$.

Indikasi peningkatan aktivitas khamir tampak dari meningkatnya kandungan ethanol, tetapi tidak disertai dengan peningkatan populasi khamir (Tabel 3), hal ini karena pada keadaan anaerob, kondisi untuk menghasilkan ethanol (Lehrian dan Patterson, 1983), sumber karbon sebagai sumber enersi tidak digunakan untuk pertumbuhan melainkan untuk pembentukan ethanol.
Tabel 3. Populasi Khamir dalam CairanFermentasi / Pulp (log CFU / g)

\begin{tabular}{lcll}
\hline \multirow{2}{*}{ Perlakuan } & \multicolumn{3}{c}{ Hari Ke- } \\
\cline { 2 - 4 } & \multicolumn{1}{c}{$\mathbf{1}$} & \multicolumn{1}{c}{$\mathbf{3}$} \\
\hline MO & $8.06^{\mathrm{e}}$ & $8.94^{\mathrm{de}}$ & $8.89^{\mathrm{ab}}$ \\
MOI & $7.13^{\mathrm{g}}$ & $8.95^{\mathrm{a}}$ & $8.59^{\mathrm{bcd}}$ \\
MX & $7.25^{\mathrm{g}}$ & $7.90^{\mathrm{f}}$ & $8.59^{\mathrm{bc}}$ \\
MXI & $7.03^{\mathrm{g}}$ & $7.72^{\mathrm{f}}$ & $8.81^{\mathrm{ab}}$ \\
MY & $7.28^{\mathrm{g}}$ & $7.73^{\mathrm{f}}$ & $8.66^{\mathrm{bcd}}$ \\
MYI & $6.98^{\mathrm{g}}$ & $8.37^{\mathrm{cde}}$ & $8.41^{\mathrm{cde}}$ \\
\hline
\end{tabular}

Keterangan: MO (tanpa tetes dan biakan), MOI (tanpa tetes, diberi biakan), MX (diberi tetes dosis 1, tanpa biakan), MXI (diberi tetes dosis 1 dan biakan), MY (diberi tetes dosis 1,5, tanpa biakan), MYI (diberi tetes dosis 1,5 dan biakan). Angka-angka yang diikuti huruf yang sama pada setiap kolom tidak berbeda nyata pada taraf $5 \%$.

\section{Perubahan Kandungan Asam}

Ketika fase anaerob dalam proses fermentasi kakao mulai terhenti, suksesi mikrobia akan dilanjutkan oleh bakteri asam asetat yang akan mengubah ethanol menjadi asam asetat (Lopez dan Dimick, 1996). Asam asetat merupakan salah satu senyawa calon rasa yang sangat penting bagi kualitas biji kakao. Hasil analisis asam asetat selama proses fermentasi disajikan pada Tabel 4.

Tabel 4. Kadar Asam Tertitrasi Cairan Fermentasi / Pulp (\%).

\begin{tabular}{llll}
\hline \multirow{2}{*}{ Perlakuan } & \multicolumn{3}{l}{ Hari Ke- } \\
\cline { 2 - 4 } & $\mathbf{1}$ & $\mathbf{2}$ & $\mathbf{3}$ \\
\hline MO & $2.27^{\text {de }}$ & $2.64^{\text {abcde }}$ & $1.32^{\mathrm{f}}$ \\
MOI & $2.74^{\text {abcd }}$ & $2.88^{\text {abcd }}$ & $1.28^{\mathrm{f}}$ \\
MX & $2.52^{\text {bcde }}$ & $3.19^{\text {abc }}$ & $1.86^{\text {ef }}$ \\
MXI & $2.33^{\text {de }}$ & $2.88^{\text {a }}$ & $1.42^{\mathrm{f}}$ \\
MY & $2.32^{\text {cde }}$ & $3.05^{\text {abcd }}$ & $2.40^{\text {cd }}$ \\
MYI & $2.74^{\text {abc }}$ & $3.16^{\text {ab }}$ & $1.35^{\mathrm{f}}$ \\
\hline
\end{tabular}

Keterangan: MO (tanpa tetes dan biakan), MOI (tanpa tetes, diberi biakan), MX (diberi tetes dosis 1, tanpa biakan), MXI (diberi tetes dosis 1 dan biakan), MY (diberi tetes dosis 1,5, tanpa biakan), MYI (diberi tetes dosis 1,5 dan biakan). Angka-angka yang diikuti huruf yang sama pada setiap kolom tidak berbeda nyata pada taraf $5 \%$. 
Pada dinamika pembentukan ethanol yang terjadi (Tabel 3), dinamika pembentukan asam mengikuti pola yang sama, hal ini karena asam yang terbentuk terutama berasal dari oksidasi ethanol menjadi asam asetat. Tampak bahwa inokulasi biakan juga meningkatkan kadar asam tertitrasi, terutama pada perlakuan tanpa tambahan tetes tebu dan perlakuan dengan penambahan tetes tebu dosis tertinggi. Peningkatan kadar asam terutama disebabkan karena adanya peningkatan populasi bakteri asam asetat (Tabel 5).

Tabel 5. Populasi Bakteri Asam Asetat dalam Cairan Fermentasi / Pulp (log CFU / g).

\begin{tabular}{llll}
\hline & \multicolumn{3}{l}{ Hari Ke- } \\
\cline { 2 - 4 } Perlakuan & 1 & 2 & 3 \\
\hline MO & $6.63^{\text {dec }}$ & $7.38^{\mathrm{c}}$ & $7.95^{\mathrm{c}}$ \\
MOI & $6.44^{\mathrm{ef}}$ & $6.92^{\mathrm{d}}$ & $9.18^{\mathrm{a}}$ \\
MX & $6.88^{\text {def }}$ & $6.57^{\text {ef }}$ & $6.65^{\mathrm{c}}$ \\
MXI & $6.85^{\text {def }}$ & $6.76^{\text {def }}$ & $7.79^{\mathrm{c}}$ \\
MY & $6.76^{\text {def }}$ & $6.80^{\text {def }}$ & $6.64^{\text {def }}$ \\
MYI & $8.22^{\mathrm{b}}$ & $6.85^{\text {de }}$ & $8.89^{\mathrm{a}}$ \\
\hline
\end{tabular}

Keterangan: MO (tanpa tetes dan biakan), MOI (tanpa tetes, diberi biakan), MX (diberi tetes dosis 1, tanpa biakan), MXI (diberi tetes dosis 1 dan biakan), MY (diberi tetes dosis 1,5, tanpa biakan), MYI (diberi tetes dosis 1,5 dan biakan). Angka-angka yang diikuti huruf yang sama pada setiap kolom tidak berbeda nyata pada taraf $5 \%$.

\section{Kualitas Biji Hasil Fermentasi}

Kualitas biji kakao hasil fermentasi ditentukan terutama oleh keasaman $(\mathrm{pH})$ dan derajat fermentasi yang diukur dengan warna bagian dalam biji. Pengolah kakao menghendaki $\mathrm{pH}$ biji antara 5,2-5,8 untuk menghasilkan cocoa butter yang berkualitas (Wood dan Lass, 2001). Brown menunjukkan warna biji yang terfermentasi sempurna dengan kenampakan biji berwarna cokelat dan permukaan berongga. Data pengamatan kualitas biji hasil fermentasi disajikan pada Tabel 6.
Tabel 6.Keasaman $(\mathrm{pH})$ dan Warna Bagian dalam Biji Hasil Fermentasi

\begin{tabular}{lll}
\hline Perlakuan & Ph Pulp & Biji Brown (\%) \\
\hline MO & $5.7^{\mathrm{a}}$ & $41.1^{\mathrm{e}}$ \\
MOI & $5.9^{\mathrm{a}}$ & $60.3^{\mathrm{b}}$ \\
MX & $5.5^{\mathrm{a}}$ & $38.1^{\mathrm{f}}$ \\
MXI & $5.6^{\mathrm{a}}$ & $42.8^{\mathrm{d}}$ \\
MY & $5.6^{\mathrm{a}}$ & $56^{\mathrm{c}}$ \\
MYI & $5.3^{\mathrm{a}}$ & $68.4^{\mathrm{a}}$ \\
\hline
\end{tabular}

Keterangan: MO (tanpa tetes dan biakan), MOI (tanpa tetes, diberi biakan), MX (diberi tetes dosis 1, tanpa biakan), MXI (diberi tetes dosis 1 dan biakan), MY (diberi tetes dosis 1,5, tanpa biakan), MYI (diberi tetes dosis 1,5 dan biakan). Angka-angka yang diikuti huruf yang sama pada setiap kolom tidak berbeda nyata pada taraf $5 \%$.

Tabel 6 dapat dilihat bahwa $\mathrm{pH}$ biji kakao hasil fermentasi yang diperlakukan dengan penambahan tetes dan biakan telah memenuhi standar yaitu berkisar antara 5,3-5,6. Penambahan biakan pada proses fermentasi tampak meningkatkan derajat fermentasi, demikian juga penambahan tetes tebu dengan dosis 1,5. Perlakuan penambahan tetes tebu dosis 1,5 dan biakan memberikan derajat fermentasi tertinggi $(68,4 \%)$ walaupun belum memenuhi standar SNI (Standar Nasional Indonesia), yaitu 89 $\%$.

\section{SIMPULAN}

Penambahan tetes tebu sebagai sumber karbon dan enersi, Saccharomyces cerevisiae dan Acetobacter aceti sebagai mikrobia pemfermentasi, dalam fermentasi biji kakao kering dapat memperbaiki proses biokimia yang terjadi, sehingga mampu memperbaiki kualitas biji terfermentasi yang dihasilkan walaupun belum memenuhi standar SNI. Perlu dilakukan penelitian lanjutan untuk mendapatkan dosis penambahan tetes tebu yang tepat. 


\section{UCAPAN TERIMAKASIH}

Terimakasih kepada PT Pagilaran yang telah memasok biji kakao dan Yoshinobu Kaneko, Osaka University, yang telah memberi biakan Sacharomyces cerevisiae OUT7055 untuk keperluan penelitian ini.

\section{DAFTAR PUSTAKA}

Anon. 1970. International Cocoa Standards. Cocoa Growers Bull. 14: 28-32.

Ardhana, M.M. and G.H. Fleet, 2003.The microbial ecology of cocoa bean fermentations in Indonesia. Int. J. Food Microbiol., 86: 87-99.

Biehl, B. 1986. Cocoa Fermentation and Problem of Acidity, Over Fermentation and Low Cocoa Flavour. Dalam: Cocoa Fermentation: Progrress and Outlook. Pusparajah, E and Chew, P.S (Eds).Incorp.Soc. And Planter. Kuala Lumpur.

Biro humas Deptan. 2010. Pencanangan Gerakan Nasional Fermentasi kakao untuk Mendukung Industri dalam Negeri. www.deptan.go.id. Diakses pada tanggal 1 September 2010.

Cutaia, A.J. 1984. Beverages: Malt Beverages and Brewing material.Dalam:Official Methods of Analysis Chemist. 14th. Edition. S. William (Ed.) Association of Analytical of Analytical Chemist, Inc. M.D.

Friend, B. A. and K. M. Shahani. 1981. Fuel alcohol production from waste materials. In Fuels from Biomass. pp. 343-355. Ed. Klass, D. K. and Emert, G. H.Ann Arbor Science Pub.Inc.

Hapsari, A.P, Y.P. Amiwaha, G.S.P. Rini, 2007. Pengaruh Pemberian Inokulum Dengan Variasi Perbandingan Komposisi Mikroorganisme dalam Proses Fermentasi terhadap Kualitas Biji Kakao Terfermentasi.Laporan Pekan Kreativitas Mahasiswa.
Haryadi dan M. Supriyanto. 1991. Pengolahan Kakao Menjadi Bahan Pangan. Proyek Peningkatan Perguruan Tinggi. Univesitas Gadjah Mada, Yogyakarta.

Jinap, S. dan P.S Dimick. 1990. Acidic Characteristic of Fermented and Dried Cocoa beans from different Countries and origin. J. Food Sci 55:547-550.

Lehrian, D.W., and G.R. Patterson. 1983. Cocoa Fermentation. Dalam : Biotechnology. Rehm, H.J. and G. Reed (Eds.) Vol.5.Verlag Chemist Gmbh, Weinhem, Germany.

Lopez, A.S. and P.S. Dimick.1995.Cocoa Fermentation. Dalam: Emzymes, Biomass, Food and Feed, $2^{\text {nd }}$ ed. Biotechnology, vol 9. Reed, G. and T.W. Nagodawithana (Ed.).VCH. Weinheim, Germany.

Miller, G.L. 1959. Use of Dinitrosalicylic Acid Reagent for Determination of Reducing Sugar.Analytical Chemistry, 31, 426.

Palupi, D.W, A.R Nusaputri., G.S.P. Rini., 2007. Pengembangan Teknologi Untuk Fermentasi Biji Kakao Kering. Laporan Grant karya Inovasi.

Schwan, R.F.1998. Cocoa Fermentations Conducted with a Defined Microbial Cocktail Inoculum ASM Vol. 64. 4.1477-1483.

Thompson, S.S., K.B, Miller., A.S, Lopez. 2000. Cocoa and Coffe. Dalam Food Microbiology and Fundamentals and Frontiers 4th. Doyle, P.M. Bechat, L.R. Montville, T.J. ASM Press. Washington DC.

Wood, G.A.R., dan R.A. Lass. 2001. Cocoa. 4 th ed. Longman. London

Yasa, I.W. 2004. Indonesian Cocoa Beans: current situation. Indonesian Cocoa Farmer Association. Indonesian Cocoa Board (ICB). 